\title{
Juvenile paracoccidioidomycosis in urban area: report of two cases
}

\begin{abstract}
We present two cases of juvenile form of paracoccidioidomycosis (PCM), a systemic mycosis frequently found in rural areas, whose prognosis is poor in children and young adults. They are a 14-year-old boy and a 25-year-old woman, both residents in an urban area in São Paulo - Brazil, without any history of travelling to an endemic area. They have been admitted to the hospital due to fever, weight loss and lymphadenopathy. The diagnosis was confirmed by serologic and histopathologic study. Patients have recovered after therapy with oral itraconazole and were discharged from hospital, maintaining outpatient visits. In this article, the authors discuss the unusual presentation of PCM in an urban area.
\end{abstract}

Keywords: juvenile paracoccidioidomycosis, lymphadenopathy, Paracoccidioides brasiliensis, urban area.

[Braz J Infect Dis 2010;14(1):77-80] @Elsevier Editora Ltda.

\section{INTRODUCTION}

PCM is a systemic, chronic granulomatous and progressive disease, caused by the dimorphic fungus Paracoccidioides brasiliensis which is restricted to Latin America. ${ }^{1,2}$ In adults the main presentation is a chronic disease, but in children and adolescents, it is usually an acute or sub-acute disease, and may be severe. ${ }^{3}$ The acute juvenile form is characterized by a rapid course and a marked involvement of the reticuloendothelial system. ${ }^{4}$ In the absence of specific therapy, mortality rates are high. ${ }^{5}$ Follow-up is required after hospital discharge, in regard the possibility of relapses. ${ }^{3}$

\section{CASE REPORT}

\section{Case 1}

Male, 14-year-old, student, from São Paulo was admitted to hospital in July 2006 with asthenia, weight loss $(4 \mathrm{~kg})$, fever $\left(39^{\circ} \mathrm{C}\right)$, low jaundice, coluria and pain in left leg. The signs and symptoms have started one month earlier. He has not travelled to any endemic areas of PCM. Physical examination revealed mild jaundice, disseminated lymphadenopathies varying from 2 to
4 centimeters in diameter, hepatosplenomegaly and a painful mass in left leg proximal extremity (Figure 1). Abdominal and cervical CT confirmed the enlargement of liver, spleen and lymph nodes (Figure 2), and X-rays of the leg showed osteoclastic lesions (Figure 3). Diagnostic is confirmed after cervical lymph node biopsy showed Paracoccidioides brasiliensis (Figure 4) and serologic test for paracoccidioidomycosis (double immunodiffusion). The patient was treated with itraconazole $200 \mathrm{mg}$ per day, with clinical improvement. Hospital discharge occurred after seven days, with subsequent outpatient visits. Itraconazole was given for six months, without any complication in the period.

\section{Case 2}

Female, pre-school teacher, natural from São Paulo, presented to the hospital in June 2006 with fever $\left(38^{\circ} \mathrm{C}\right)$, malaise, weight loss $(3 \mathrm{~kg})$, generalized arthralgia and lymphadenopathies ranging from 1 to 2 centimeters in diameter. Symptoms have started twenty days before hospital admission. She had never been to endemic areas. Physical examination revealed moderate mucocutaneous pallor, hepatosplenomegaly and generalized
Authors

Rodrigo da Costa

Carneiro ${ }^{1}$

Bianca Grassi de

Miranda ${ }^{2}$

Carlos Camilo Neto ${ }^{3}$,

Marina K Tsukumo ${ }^{4}$

Cibele LC Fonseca ${ }^{5}$

João Silva de Mendonça ${ }^{6}$

${ }^{1,2}$ Residents of Infectious

Diseases Department,

Hospital do Servidor

Público Estadual,

${ }^{3}$ Resident of Pathology

Department, Hospital do

Servidor Público Estadual,

4,5 Preceptors of Infectious

Diseases Department,

Hospital do Servidor

Público Estadual,

${ }^{6}$ Director of Infectious

Diseases Department,

Hospital do Servidor

Público Estadual.
Submitted on: 04/15/2009 Approved on: 05/19/2009

Correspondence to: RC Carneiro

Resident of Infectious Diseases Department,

Hospital do Servidor Público Estadual, Rua Pedro de Toledo, n. 1800, CEP 04039-004, São Paulo, SP, Brazil. Telephone/Fax number: 551155491565

E-mail: rodrigoccarneiro @gmail.com

We declare no conflict of interest. 
Figure 1: Mass in cervical region.

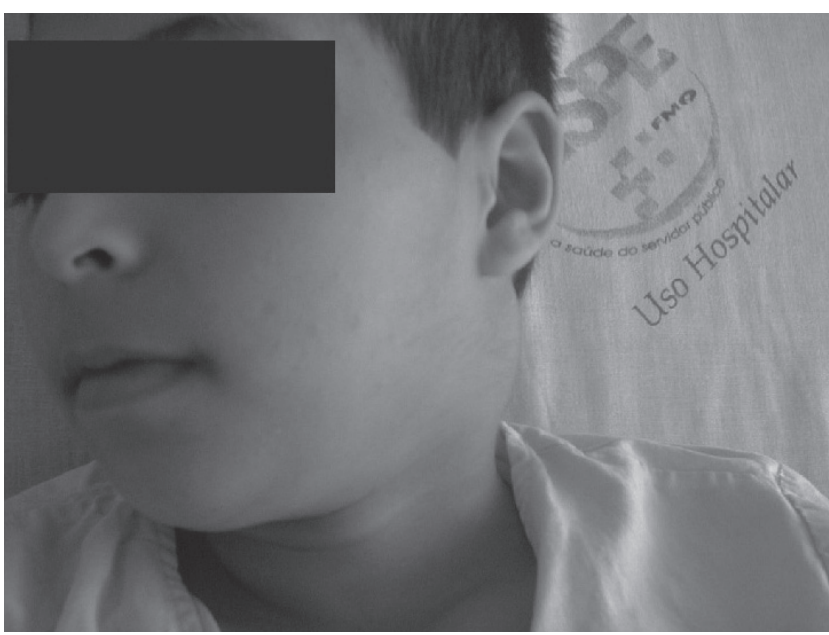

Figure 2: Multiple cervical lymphadenopathy on CT.

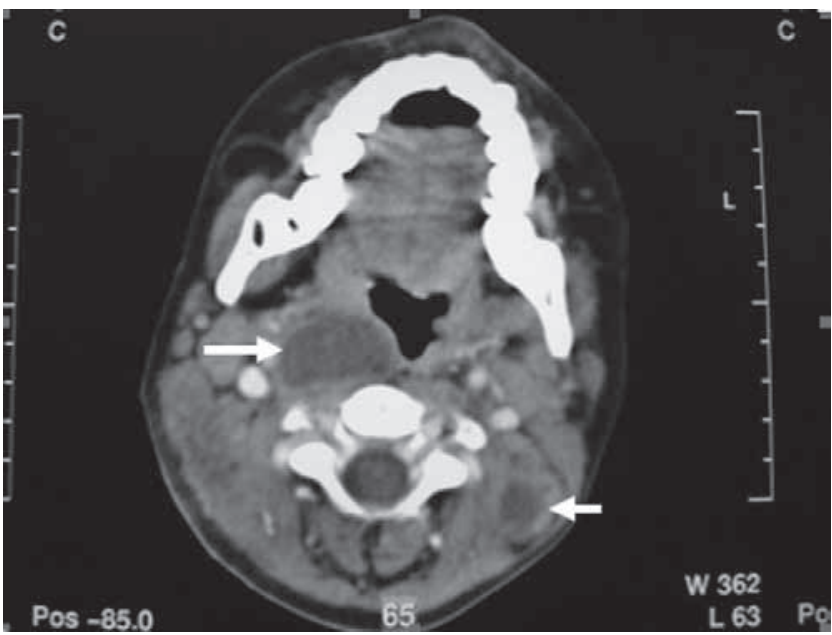

Figure 3: Radiography showing bone reabsorption in the proximal tibia.

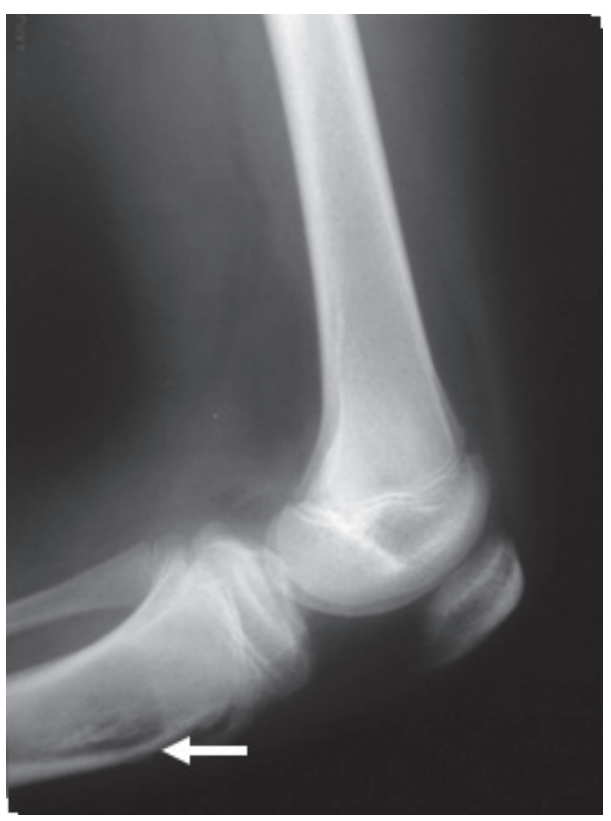

Figure 4: A. Granulomatous reaction with foreign body giant cell in cervical lymph node, stained by Hematoxylin Eosin, X100 (case 1).

B. Paracoccidioides brasiliensis in giant cell, cervical lymph node stained by PAS, X630 (case 2).

C. Paracoccidioides brasiliensis in cervical lymph node, stained by grocott, X1000 (case 2).

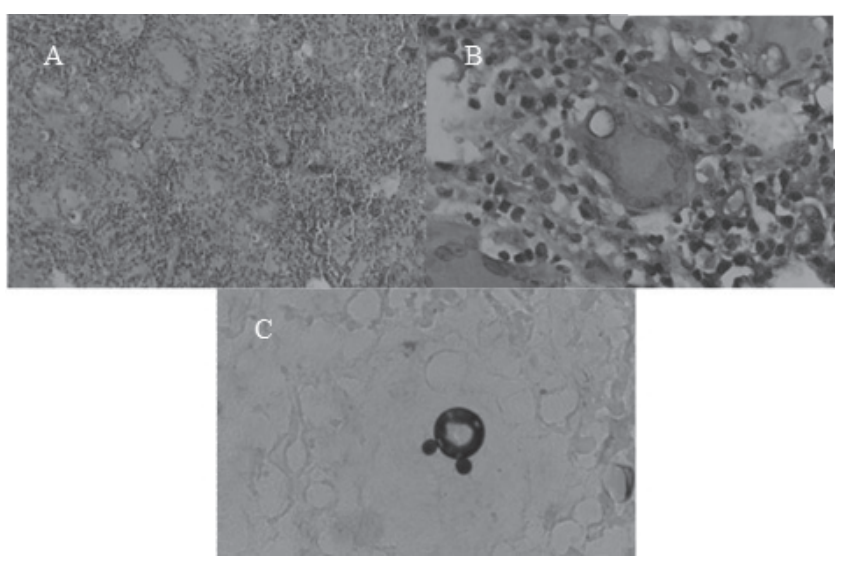

lymphadenopathy. Abdominal CT scan confirmed enlargement of the liver and the spleen. Diagnosis is confirmed after cervical lymph node biopsy showed the same findings of case 1 and serologic test for paracoccidioidomycosis (double immunodiffusion). The treatment was initiated with oral itraconazole $200 \mathrm{mg}$ per day and persisted for 6 months. The patient presented a rapid improvement and was discharged from hospital 8 days after admission, with outpatient followup. After 3 months of treatment, the serology marks became negative.

Laboratorial tests of both patients are presented in Tables 1 and 2 .

\section{DISCUSSION}

Both patients reported in this article presented with the acute form of PCM, consistent with others reports of the disease in children and adolescents. ${ }^{6-8}$ Most of clinical manifestations were related to the reticuloendothelial system, such as lymph node enlargement, hepatomegaly and splenomegaly. ${ }^{9}$ Lymphadenopaty is the most frequent manifestation followed by fever. ${ }^{10}$ Both were present in our patients.

Hepatic disorders are one of the most reported abnormalities ${ }^{3,11}$ and were presented in our patients, both with increase in alkaline phosphatase and gamma-glutamyl transferase. In case 1 jaundice was observed, this manifestation is associated with poor prognosis. ${ }^{12,13}$ All hepatic changes improved with treatment and the patients didn't show late complications, such as portal hypertension or cholecystitis, in the follow-up period.

Pereira et al. showed bone involvement in $20 \%$ of 38 patients with juvenile form of PCM. ${ }^{9}$ In our case one, osteoclastic lesions were present and had clinical and radiological resolution after therapy. 
Table 1. Laboratorial tests of case 1

\begin{tabular}{|c|c|c|c|c|}
\hline Case 1 & Admission & Discharge & 3 months evaluation & 6 months evaluation \\
\hline $\mathrm{Hb}$ & $11.3 \mathrm{~g} / \mathrm{dL}$ & $12.3 \mathrm{~g} / \mathrm{dL}$ & $13.1 \mathrm{~g} / \mathrm{dL}$ & $14.3 \mathrm{~g} / \mathrm{dL}$ \\
\hline $\mathrm{Ht}$ & $32.8 \%$ & $37.3 \%$ & $38 \%$ & $40 \%$ \\
\hline WBC & $12.600 \mathrm{cel} / \mathrm{mm}^{3}$ & $10.670 \mathrm{cel} / \mathrm{mm}^{3}$ & $7.010 \mathrm{cel} / \mathrm{mm}^{3}$ & $7.500 \mathrm{cel} / \mathrm{mm}^{3}$ \\
\hline Neutrophils & $9.400 \mathrm{cel} / \mathrm{mm}^{3}$ & $6.700 \mathrm{cel} / \mathrm{mm}^{3}$ & $3.900 \mathrm{cel} / \mathrm{mm}^{3}$ & $3.900 \mathrm{cel} / \mathrm{mm}^{3}$ \\
\hline Platelets & $581.000 / \mathrm{mm}^{3}$ & $416.000 / \mathrm{mm}^{3}$ & $351.000 / \mathrm{mm}^{3}$ & $310.000 / \mathrm{mm}^{3}$ \\
\hline ESR & $120 \mathrm{~mm} / \mathrm{h}$ & $70 \mathrm{~mm} / \mathrm{h}$ & $30 \mathrm{~mm} / \mathrm{h}$ & $10 \mathrm{~mm} / \mathrm{h}$ \\
\hline ALT & $121 \mathrm{U} / \mathrm{L}$ & $84 \mathrm{U} / \mathrm{L}$ & $16 \mathrm{U} / \mathrm{L}$ & $18 \mathrm{U} / \mathrm{L}$ \\
\hline AST & $131 \mathrm{U} / \mathrm{L}$ & $119 \mathrm{U} / \mathrm{L}$ & $37 \mathrm{U} / \mathrm{L}$ & $26 \mathrm{U} / \mathrm{L}$ \\
\hline $\mathrm{AF}$ & $3260 \mathrm{U} / \mathrm{L}$ & $2111 \mathrm{U} / \mathrm{L}$ & $558 \mathrm{U} / \mathrm{L}$ & $420 \mathrm{U} / \mathrm{L}$ \\
\hline$\gamma \mathrm{GT}$ & $841 \mathrm{U} / \mathrm{L}$ & $585 \mathrm{U} / \mathrm{L}$ & $61 \mathrm{U} / \mathrm{L}$ & $26 \mathrm{U} / \mathrm{L}$ \\
\hline Albumin & $3.8 \mathrm{~g} / \mathrm{dL}$ & $4.3 \mathrm{~g} / \mathrm{dL}$ & $4.2 \mathrm{~g} / \mathrm{dL}$ & $4.2 \mathrm{~g} / \mathrm{dL}$ \\
\hline $\mathrm{RCP}$ & $8.14 \mathrm{mg} / \mathrm{dL}$ & $1.2 \mathrm{mg} / \mathrm{dL}$ & $0.9 \mathrm{mg} / \mathrm{dL}$ & $0.8 \mathrm{mg} / \mathrm{dL}$ \\
\hline Bil (T/D) & $2.6 / 1.6 \mathrm{mg} / \mathrm{dL}$ & $2.2 / 1.3 \mathrm{mg} / \mathrm{dL}$ & $1.8 / 1.0 \mathrm{mg} / \mathrm{dL}$ & $0.9 / 0.4 \mathrm{mg} / \mathrm{dL}$ \\
\hline
\end{tabular}

Hb - Hemoglobin, Ht - Hematocrit, WBC - White blood cell count, ESR - Erythrocyte sedimentation rate, ALT - Alanine aminotransferase, AST - Aspartate aminotransferase, AF - Alkaline phosphatase, $\gamma \mathrm{GT}$ - Gamma-glutamyl transferase, RCP - Reactive C protein, Bil (T/D) - Bilirrubin (Total/Direct)

Table 2. Laboratorial tests of case 2

\begin{tabular}{lcccc}
\hline Case 2 & Admission & Discharge & 3 months evaluation & 6 months evaluation \\
\hline $\mathrm{Hb}$ & $10.0 \mathrm{~g} / \mathrm{dL}$ & $9.9 \mathrm{~g} / \mathrm{dL}$ & $15.5 \mathrm{~g} / \mathrm{dL}$ & $13.9 \mathrm{~g} / \mathrm{dL}$ \\
\hline $\mathrm{Ht}$ & $29.2 \%$ & $29.8 \%$ & $43.6 \%$ & $4.3 \%$ \\
\hline WBC & $17.200 \mathrm{cel} / \mathrm{mm}^{3}$ & $13.300 \mathrm{cel} / \mathrm{mm}^{3}$ & $11.660 \mathrm{cel} / \mathrm{mm}^{3}$ & $\mathrm{cel} / \mathrm{mm}^{3}$ \\
\hline Neutrophils & $11.400 \mathrm{cel} / \mathrm{mm}^{3}$ & $7.200 \mathrm{cel} / \mathrm{mm}^{3}$ & $9.700 \mathrm{cel} / \mathrm{mm}^{3}$ & $2.800 \mathrm{cel} / \mathrm{mm}^{3}$ \\
\hline Platelets & $456.000 / \mathrm{mm}^{3}$ & $423.000 / \mathrm{mm}^{3}$ & $233.000 / \mathrm{mm}^{3}$ & $212.000 / \mathrm{mm}^{3}$ \\
\hline ESR & $91 \mathrm{~mm} / \mathrm{h}$ & $60 \mathrm{~mm} / \mathrm{h}$ & $20 \mathrm{~mm} / \mathrm{h}$ & $22 \mathrm{~mm} / \mathrm{h}$ \\
\hline ALT & $13 \mathrm{U} / \mathrm{L}$ & $15 \mathrm{U} / \mathrm{L}$ & $20 \mathrm{U} / \mathrm{L}$ & $12 \mathrm{U} / \mathrm{L}$ \\
\hline AST & $26 \mathrm{U} / \mathrm{L}$ & $32 \mathrm{U} / \mathrm{L}$ & $41 \mathrm{U} / \mathrm{L}$ & $32 \mathrm{U} / \mathrm{L}$ \\
\hline AF & $146 \mathrm{U} / \mathrm{L}$ & $132 \mathrm{U} / \mathrm{L}$ & $115 \mathrm{U} / \mathrm{L}$ & $95 \mathrm{U} / \mathrm{L}$ \\
\hline$\gamma$ GT & $46 \mathrm{U} / \mathrm{L}$ & $33 \mathrm{U} / \mathrm{L}$ & $11 \mathrm{U} / \mathrm{L}$ & $2 \mathrm{U} / \mathrm{L}$ \\
\hline Albumin & $2.7 \mathrm{~g} / \mathrm{dL}$ & $3.2 \mathrm{~g} / \mathrm{dL}$ & $4.0 \mathrm{~g} / \mathrm{dL}$ & $4.3 \mathrm{~g} / \mathrm{dL}$ \\
\hline RCP & $10.26 \mathrm{mg} / \mathrm{dL}$ & $4.75 \mathrm{mg} / \mathrm{dL}$ & $1.1 \mathrm{mg} / \mathrm{dL}$ & $1.0 \mathrm{mg} / \mathrm{dL}$ \\
\hline Bil (T/D) & $0.7 / 0.2 \mathrm{mg} / \mathrm{dL}$ & $0.6 / 0.1 \mathrm{mg} / \mathrm{dL}$ & $0.7 / 0.2 \mathrm{mg} / \mathrm{dL}$ & $0.2 / 0 \mathrm{mg} / \mathrm{dL}$ \\
\hline
\end{tabular}

Hb - Hemoglobin, Ht - Hematocrit, WBC - White blood cell count, ESR - Erythrocyte sedimentation rate, ALT - Alanine aminotransferase, AST - Aspartate aminotransferase, AF - Alkaline phosphatase, $\gamma \mathrm{GT}$ - Gamma-glutamyl transferase, RCP - Reactive C protein, Bil (T/D) - Bilirrubin (Total/Direct) 
The identification of fungal elements suggestive of $P$. brasiliensis in lymph nodes and suspected organs biopsy, or by direct examination of sputum and other clinical specimens, is considerate the gold standard for diagnosis of PCM. Serological test are important in diagnosis and during the follow up in regard to define treatment success. Therapy is successful when serologic titers become negative or remain stable in 1:2 after appropriated therapy. Double immunodiffusion reaction has $80 \%$ of sensibility and more than $90 \%$ of specificity, otherwise it is an easy laboratorial method.,

In the reported cases, histopathologic study of cervical lymph nodes resulted compatible with $P$. brasiliensis, and the double immunodiffusion reaction was positive initially, with further rise in serology titers, that became negative during treatment with itraconazole. In both patients, serologic tests for histoplamosis resulted negative.

In the cases here presented itraconazole was the therapy of choice according to the Brazilian Paracoccidiodomycosis Consensus recommendations for therapy of mild to moderate cases. ${ }^{3}$ Itraconazole is well tolerated and effective. Both patients had clinical and serologic improvement, with hospitalization for short period and outpatient visits for six months after ending therapy.

In the last few years, changes in the demographic and geographic patterns of the population with PCM have been observed. The urbanization progress that causes increase in rural population may justify the occurrence of PCM in urban areas. Although, risk factors cannot be identified. ${ }^{14-17}$ The cases here presented did not have any recognized risk factor that could explain the acquisition of PCM, for both patients have lived in strictly urban areas, denied any rural contact.

\section{CONCLUSION}

Paracoccidioidomycosis is the major systemic mycosis in Latin America. It is usually related to rural areas but in last decades the epidemiology has been changing to urban areas, beforehand not characterized like to be endemic. The juvenile form is associated with worse prognosis and high mortality hates. Clinicians must be aware about this condition in endemic regions.

\section{ACKNOWLEDGEMENTS}

We thank Luiz Celso Mattosinho França for the histopathological background.

\section{REFERENCES}

1. Lacaz CS, Porto E, Martins JEC. Paracoccidioidomicose. In: Lacaz CS, Porto E, Martins JEC.eds. Micologia Médica, São Paulo: Sarvier Editora, 1991.

2. Brummer E, Castañeda E, Restrepo A. Paracoccidioidomycosis: an update. Clin Microbiol Revs 1993; 6:89-117.

3. Shikanai-Yasuda MA, Filho FQT, Mendes RP, Colombo AL, Moretti ML. Consenso em paracoccidioidomicose. Rev Soc Bras Med Trop 2006; 39(6):297-310.

4. Pellegrino A, De Capriles CH, Magaldi S, De Oca IM, Ruiz ME, Pérez C, Mata-Essayag S. Am J Trop Med Hyg 2003; 68(3):301-303.

5. Mota NG, Rezkallah-Iwasso MT, Peracoli MT et al. Correlation between cell-mediated immunity and clinical forms of paracoccidioidomycosis. Trans R Soc Pro Med Hyg 1985; 79:765-772.

6. Franco M, Montenegro MR, Mendes RP, Marques SA, Dilon NL, Mota NGS. Paracoccidioidomycosis: A recently proposed classification of its clinical forms. Rev Soc Bras Med Trop 1987; 20(20):129-132.

7. Lodero AT, Gonçalves AJR, Cruz MLS. Paracoccidioidomicose disseminada "infanto-juvenil" em adolescentes. Arq Bras Med 1987; 61(1):5-12.

8. Fonseca ERS, Pardal PPO, Severo LC. Paracoccidioidomicose em crianças do Belém do Pará. Rev Soc Bras Med Trop 1999; 32(1):31-3.

9. Pereira RM, Bucaretchi F, Barison ED, Hessel G, Tresoldi AT. Paracoccidioidomycosis in children: Clinical presentation, follow-up and outcome. Rev Soc Bras Med Trop 2004; 46(3):127-31.

10. Nogueira MGS, Andrade GMQ, Tonelli E. Clinical evolution of paracoccidioidomycosis in 38 children and teenagers. Mycopathologia 2006; 161:73-81.

11. Chaib E, Oliveira CMC, Prado OS. Obstructive jaundice caused by blastomycosis of the lymph nodes around the common bile duct. Arq Gastroent 1988; 25:198-2.

12. Andrade ALSS. Paracoccidioidomicose linfático-abdominal - Contribuição ao seu estudo. Revista de Patologias Tropicais 1983; 12(3):165-256.

13. Barbosa W, Andrade ALSS. Hepatic involvement in paracoccidioidomycosis. Revista de Patologias Tropicais 1983; 12(3):295-305.

14. Lacaz CS, Porto E, Martins JEC, Heins-Vaccari EM, Melo NT. Paracoccidioidomicose. In: Lacaz CS, Porto E, Martins JEC, Heins-Vaccari EM, Melo NT, eds. Tratado de Micologia Médica Lacaz. São Paulo: Savier, 2002.

15. Restrepo-Moreno A. Ecology of Paracoccidioides brasiliensis. In: Franco MF, Lacaz CS, Restrepo-Moreno A, Del Negro G, eds. Paracoccidioidomycosis. Boca Raton: CRS Press, 1994.

16. Valle ACF, Wanke B, Wanke N, Peixoto TC, Perez M. Tratamento da paracoccidioidomicose: estudo retrospectivo de 500 casos. I-Análise clínica, laboratorial e epidemiológica. Anais Brasileiros de Dermatologia 1992; 67:251-4.

17. Wanke B, Londero AT. Epidemiology and paracoccidioidomycosis infection. In: Franco MF, Lacaz CS, RestrepoMoreno A, Del Negro G, eds. Paracoccidioidomycosis. Boca Raton: CRS Press, 1994. 